after a meal. Thus diabetic patients defined as those with random venous concentrations of at least $11 \mathrm{mmol} / 1(198 \mathrm{mg} / 100 \mathrm{ml})$ will be five standard deviations or more above the highest postprandial mean blood glucose concentration. Although we cannot say that we did not miss some diabetic patients in our series, these data suggest that this was unlikely; the incidence too (four in 2403 or one in 600 of a female population of reproductive years) was about the expected figure.

The stages of pregnancy at which samples for random determination of glucose concentration were obtained were those when blood was required for other routine antenatal tests; thus the cost of the needle and syringe was shared with several other tests. If the commonly used Multistix for testing urine, which give much unnecessary data and cost about 8 pence each, were replaced by a simple reagent strip to detect proteinuria only (at about 4 pence) the savings would help to compensate for the automated measurement of the blood glucose concentration. Clinic routine is not disrupted, the patients are not delayed or inconvenienced, and any increased laboratory cost can be balanced by saving on unnecessary urine tests. On the basis of random blood glucose screening two patients were diagnosed as having diabetes mellitus and 32 were correctly referred for an oral glucose tolerance test-that is, excluding the six patients in whom the blood glucose concentrations did not exceed the cut off values. Of these, a further two were found to have diabetes and 11 impaired glucose tolerance. Of 21 women referred for an oral glucose tolerance test for other reasons, three had impaired glucose tolerance. From another viewpoint, none of the diabetic patients was missed by the random checking of blood glucose concentration but only one of the four might have been referred for an oral glucose tolerance test on the basis of her glycosuria.

Is it necessary, however, to look for diabetes mellitus at all ? The incidence of diabetes appears to be increasing rather than decreasing, ${ }^{89}$ and, though mortality and morbidity rates for females appear to be better than for males, they are still high ${ }^{10}$ and show wide regional variations. The sooner pregnant diabetic women can be detected and returned to a normoglycaemic state the better their prognosis should be. The obstetrician must also be concerned for the fetus. In many hospitals now the perinatal mortality for diabetic mothers is not much greater than for the population at large, ${ }^{11}$ which almost certainly reflects the increasing care taken in controlling the metabolic state of the mother. If a look for diabetes mellitus is accepted as a necessary part of good antenatal care random measurement of blood glucose concentration offers an easy, efficient, and relatively inexpensive method for doing this.

We thank Professor K G M M Alberti, Dr P A Smith, and our colleagues in the department of clinical biochemistry of the Royal Victoria Infirmary, Newcastle upon Tyne, for their help and cooperation with this study.

\section{References}

1 Lind $\mathrm{T}$, Hytten FE. The excretion of glucose during normal pregnancy. fournal of Obstetrics and Gynaecology of the British Commonwealth 1972;79: $961-5$

2 Davison JM, Lovedale C. The excretion of glucose during normal pregnancy and after delivery. Fournal of Obstetrics and Gynaecology of the British Common-

3 wHO. Expert Committee on Diabetes Mellitus. Report. WHO Tech Rep Ser $1980 ;$ No 646

Keen H, Jarrett RJ, Alberti KGMM. Diabetes mellitus: a new look at diagnostic criteria. Diabetologia $1979 ; 16: 283-6$

sification and diagnosis of diabetes mellitus Diabetes 1979;28:1039-57.

ind $T$, McDougall AN. Antenatal screening for diabetes mellitus by random blood glucose sampling. Br f Obstet Gynaecol 1981;88:346-51.

FitzGerald MG, Keen $\mathrm{H}$. Diagnostic classification of diabetes. Lancet 1964; $1325-6$

8 Melton LJ 3rd, Pasquale J, Palumbo PJ, Chu CP. Incidence of diabetes mellitus by clinical type. Diabetes Care 1983;6:75-86.

Calnan M, Peckham CS. Incidence of insulin-dependent diabetes in the first sixteen years of life. Lancet 1977; i:589-90.

10 Patterson CC, Thorogood M, Smith PG, Heasman MA, Clarke JA, Mann JI Epidemiology of type 1 (insulin-dependent) diabetes in Scotland 1968-1976 evidence of an increasing incidence. Diabetologia 1983;24:238-43.

11 Molsted-Pederson L. Preterm labour and perinatal mortality in diabetic pregnancy-obstetric considerations. In: Sutherland HW, Stowers JM, eds. 1978:392-406.

(Accepted 26 September 1984)

\title{
HLA-DR typing in coeliac disease: evidence for genetic heterogeneity
}

\author{
A ELLIS, C J TAYLOR, M DILLON-REMMY, J C WOODROW, R B MCCONNELL
}

\begin{abstract}
Sixty nine propositi from a family study of coeliac disease were typed for HLA-DR antigens. Sixty three (91\%) were found to carry the antigen DR3, which was a significantly greater proportion $\left(p=6 \times 10^{-24}\right)$ than among the 168 controls $(26 \%)$. Concurrently 42 children
\end{abstract}

Gastroenterology Unit, Broadgreen Hospital, Liverpool L14 3LB A ELLIS, MD, MRCP, consultant physician and gastroenterologist

R B MCCONNELL, MD, FRCP, consultant physician and gastroenterologist

Department of Child Health and Tropical Child Health, Alder Hey Children's Hospital, Liverpool L12 2AP

C J TAYLOR, MRCP, lecturer

M DILLON-REMMY, MB, DTCH, research assistant

Department of Medicine, University of Liverpool, Liverpool L69 3BX J C WOODROW, MD, FRCP, professor of medicine

Correspondence to: Dr A Ellis. with the disease were DR typed. Not only was the frequency of DR3 significantly increased in these patients ( $86 \%$ versus $26 \%$ in controls; $p=3.1 \times 10^{-12}$ ) but so also was the frequency of DR7 (patients $60 \%$, controls $29 \%$; $\left.p=5.8 \times 10^{-4}\right)$. When those propositi whose coeliac disease presented before the age of 20 were combined with the childhood coeliac group and a comparison made between these patients and the remainder of the propositi, all of whom presented when they were older than 20 , the childhood onset group had a significant excess of DR7 $\left(p=2.2 \times 10^{-3}\right)$ and a significant deficiency of DR2 $\left(\mathbf{p}=3.5 \times 10^{-3}\right)$.

These findings indicate that childhood coeliac disease and adult coeliac disease are genetically heterogeneous.

\section{Introduction}

An association between coeliac disease and the histocompatibility antigen HLA-DR3 has been reported in all the populations 
in which it has been studied. ${ }^{1-8}$ In some of these studies an association between coeliac disease and another DR locus antigen, DR7, has also been observed..$^{2-5} 6$ To explain these observations it has been postulated that there is a single coeliac disease gene in linkage disequilibrium with DR3 in all populations and with DR7 in some but not all populations. We have published the results of a family study into coeliac disease carried out in Liverpool. ${ }^{9}$ A preliminary analysis of the HLA-DR frequencies of several of the propositi from that study showed an association with DR3 but not DR7. Because of the difficulties that may sometimes be encountered in differentiating coeliac disease from other causes of a flat mucosa in childhood, and because of the possibility that childhood coeliac disease might be a heterogeneous disorder with permanent or transient gluten intolerance, we decided to look separately at a group of children with coeliac disease who fulfilled all the ESPGAN criteria for the diagnosis. ${ }^{10}$ Analysis of that group of patients disclosed an association with both HLA-DR3 and DR7. Those results suggested that the association between coeliac disease and HLA-DR7 may be an age related phenomenon. We therefore decided to study the HLA-DR antigen frequencies in a larger series of both groups of patients and to compare the frequencies in the children with those in the adults. This paper describes our results.

\section{Subjects and methods}

Patients-Sixty nine propositi from the family study in Liverpool were HLA-DR typed. The age at clinical onset of the disease ranged widely from infancy to adulthood. The diagnosis of coeliac disease was based on a jejunal biopsy showing total or subtotal villous atrophy with a positive clinical response to the withdrawal of gluten from the diet, an improvement in biochemical or haematological values, and, in most cases, histological improvement. Forty two children who fulfilled all the ESPGAN criteria for coeliac disease were DR typed. There were 24 girls and 18 boys, and all were under 20 at the time of diagnosis (range 1 month to 11 years 10 months, mean 2 years 1 month). There was no overlap between the two groups of patients.

Controls-The control series consisted of 168 medical students and members of staff from the same geographical area.

$H L A-D R$ typing was carried out using a cytotoxicity technique employing an adaptation of the two colour fluorescence method. ${ }^{11}$ The panel of sera used allowed typing for seven specificities.

Statistical analysis-Fisher's exact test (two tailed) was used for the comparison of antigen frequencies.

\section{Results}

Table I lists the frequencies of the seven DR specificities tested in the control group and in the two groups of patients. The only significant positive association seen in the general series of 69 patients with coeliac disease was in respect of DR3, the relative risk being $27 \cdot 3\left(\mathrm{p}=9 \cdot 6 \times 10^{-24}\right)$. By contrast, the series of 42 patients with disease of early onset showed a positive association for both DR3 (relative risk $15.7 ; \mathrm{p}-3 \cdot 1 \times 10^{-12}$ ) and DR7 (relative risk 3.5 ; p $\left.5.8 \times 10^{-4}\right)$. Of additional interest was that the most notable negative association in the former group concerned DR 1 (relative risk $\left.0.09 ; \mathrm{p}-1.5 \times 10^{-4}\right)$, while in the latter group both DR1 and DR2 appeared to be negatively associated $(0.05$ and 0.09 respectively). (In the first analysis two pairs of subjects were closely related but, as they were ascertained independently, all were included. In the second analysis only the first ascertained of each pair was included.)

Table II gives the relevant antigen frequencies when the patients as a whole were subdivided into those with clinical onset below the age of 20 and those with later onset. Comparison of the two groups showed a significant difference in the frequencies of DR7 (p $\left.2 \cdot 2 \cdot 10^{-3}\right)$. DR2 was significantly less frequent in the early onset group $\left(\mathrm{p}=3.5 \times 10^{-3}\right)$.

TABLE I-Frequencies of HLA-DR antigens in 69 propositi from coeliac family study, 42 children with coeliac disease, and controls

\begin{tabular}{|c|c|c|c|c|c|c|c|c|c|c|}
\hline \multirow{2}{*}{ Antigen } & \multicolumn{2}{|c|}{ Controls $(n=168)$} & \multicolumn{3}{|c|}{ Propositi from family study $(n=69)$} & \multirow{2}{*}{$\mathrm{p}$} & \multicolumn{3}{|c|}{ Children with coeliac disease $(n=42)$} & \multirow{2}{*}{$\mathrm{p}$} \\
\hline & No positive & " positive & No positive & $\therefore$ positive & Relative risk & & No positive & $"$ "positive & Relative risk & \\
\hline $\begin{array}{l}\text { DR1 } \\
\text { DR2 } \\
\text { DR3 } \\
\text { DR4 } \\
\text { DR5 } \\
\text { DR6 } \\
\text { DR7 }\end{array}$ & $\begin{array}{l}32 \\
48 \\
44 \\
59 \\
21 \\
26 \\
49\end{array}$ & $\begin{array}{l}19 \\
29 \\
26 \\
35 \\
13 \\
16 \\
29\end{array}$ & $\begin{array}{r}1 \\
15 \\
63 \\
8 \\
2 \\
5 \\
23\end{array}$ & $\begin{array}{r}1 \\
22 \\
91 \\
12 \\
3 \\
7 \\
33\end{array}$ & $\begin{array}{r}0.09 \\
0.71 \\
27.30 \\
0.25 \\
0.25 \\
0.46 \\
1.20\end{array}$ & $\begin{array}{l}1.5 \times 10^{4} \\
0.36 \\
9.6 \times 10^{2} .4 \\
2.4 \times 10^{4} \\
0.03 \\
0.13 \\
0.63\end{array}$ & $\begin{array}{r}0 \\
1 \\
36 \\
6 \\
4 \\
2 \\
25\end{array}$ & $\begin{array}{r}0 \\
2 \\
86 \\
14 \\
10 \\
5 \\
60\end{array}$ & $\begin{array}{r}0.05 \\
0.09 \\
15.70 \\
0.33 \\
0.80 \\
0.33 \\
3.52\end{array}$ & $\begin{array}{l}8.1 \times 10^{-4} \\
1.2 \times 10^{-4} \\
3.1 \times 10^{12} \\
0.011 \\
0.82 \\
0.098 \\
5.8 \times 10^{4}\end{array}$ \\
\hline
\end{tabular}

TABLE II-Comparison of frequencies of HLA-DR in adults and children with coeliac disease

\begin{tabular}{|c|c|c|c|c|c|}
\hline \multirow{2}{*}{ Antigen } & \multicolumn{2}{|c|}{ Onset before 20 years } & \multicolumn{2}{|c|}{ Onset after 20 years } & \multirow{2}{*}{$\mathrm{p}$} \\
\hline & No positive & ${ }_{0}^{\circ}$ positive & No positive & ${ }^{\circ}$ positive & \\
\hline $\begin{array}{l}\text { DR1 } \\
\text { DR2 } \\
\text { DR3 } \\
\text { DR4 } \\
\text { DR5 } \\
\text { DR6 } \\
\text { DR7 }\end{array}$ & $\begin{array}{r}0 \\
3 \\
56 \\
9 \\
4 \\
2 \\
36\end{array}$ & $\begin{array}{r}0 \\
5 \\
89 \\
14 \\
6 \\
3 \\
57\end{array}$ & $\begin{array}{r}1 \\
12 \\
41 \\
5 \\
2 \\
4 \\
12\end{array}$ & $\begin{array}{r}2 \\
26 \\
89 \\
11 \\
4 \\
9 \\
26\end{array}$ & $\begin{array}{l}0.84 \\
3.5 \times 10^{-3} \\
1.0 \\
0.82 \\
1.0 \\
0.41 \\
2.2 \times 10^{-3}\end{array}$ \\
\hline
\end{tabular}

\section{Discussion}

These results show that (in Liverpool) there are significant differences in the frequencies of certain HLA antigens between those patients with coeliac disease who present before the age of 20 and those who present later. This suggests that these two subgroups of patients with coeliac disease differ genetically. In particular, coeliac disease in adults appears to be associated with DR3, whereas with an earlier onset the association is with both DR3 and DR7. It is of additional interest that DR2 was significantly reduced in frequency in the early onset group only.

TABLE III-Frequencies of HLA-DR antigens in coeliac disease in present study compared with frequencies in previous studies separated according to age of patients $(P)$ and controls $(C)$

\begin{tabular}{|c|c|c|c|c|c|c|c|c|c|c|c|c|c|c|c|c|c|}
\hline \multirow[b]{2}{*}{ Antigen } & \multicolumn{8}{|c|}{ Childhood studies } & \multicolumn{3}{|c|}{ Present study } & \multicolumn{6}{|c|}{ Adult studies } \\
\hline & \multicolumn{2}{|c|}{ Italy $^{3}$} & \multicolumn{2}{|c|}{ Spain ${ }^{4}$} & \multicolumn{2}{|c|}{$\begin{array}{l}\text { Austria/Southern } \\
\text { Germany }{ }^{2}\end{array}$} & \multicolumn{2}{|c|}{ Finland ${ }^{6}$} & \multicolumn{2}{|c|}{ Children } & $\frac{\text { Adults }}{\mathrm{P}}$ & \multicolumn{2}{|c|}{ France 5} & \multicolumn{2}{|c|}{ Holland ${ }^{3}$} & \multicolumn{2}{|c|}{ Ireland ${ }^{7}$} \\
\hline $\begin{array}{l}\text { DR1 } \\
\text { DR2 } \\
\text { DR3 } \\
\text { DR4 } \\
\text { DR5 } \\
\text { DR6 } \\
\text { DR7 }\end{array}$ & $\begin{array}{r}P_{0} \\
0 \\
4 \\
60 \\
9 \\
22 \\
9 \\
67\end{array}$ & $\begin{array}{l}\mathrm{C} \\
15 \\
26 \\
22 \\
19 \\
35 \\
44 \\
28\end{array}$ & $\begin{array}{r}P_{4} \\
4 \\
4 \\
77 \\
0 \\
23 \\
4 \\
69\end{array}$ & $\begin{array}{l}\mathrm{C} \\
22 \\
26 \\
18 \\
16 \\
24 \\
26 \\
44\end{array}$ & $\begin{array}{l} \\
\\
6 \\
6 \\
63 \\
10 \\
21 \\
28 \\
41\end{array}$ & $\begin{array}{l}\mathrm{C} \\
20 \\
28 \\
20 \\
27 \\
6 \\
20 \\
28\end{array}$ & $\begin{array}{l}\frac{P}{75} \\
\frac{85}{66}\end{array}$ & $\begin{array}{l}\frac{C}{24} \\
\frac{2}{2} \\
\frac{11}{11}\end{array}$ & $\begin{array}{r}P^{P} \\
0 \\
5 \\
89 \\
14 \\
6 \\
3 \\
57\end{array}$ & $\begin{array}{l}\text { C } \\
19 \\
29 \\
26 \\
35 \\
13 \\
16 \\
29\end{array}$ & $\begin{array}{r}\mathrm{P} \\
2 \\
26 \\
89 \\
11 \\
4 \\
9 \\
26\end{array}$ & $\begin{array}{l}\frac{P}{\bar{C}} \\
\frac{6}{2} \\
\frac{5}{55}\end{array}$ & $\begin{array}{l}\frac{\mathrm{C}}{\overline{13}} \\
\frac{1}{\overline{10}}\end{array}$ & $\begin{aligned} P \\
13 \\
29 \\
96 \\
8 \\
0 \\
13 \\
21\end{aligned}$ & $\begin{array}{l}\mathrm{C} \\
20 \\
32 \\
22 \\
31 \\
23 \\
34 \\
23\end{array}$ & $\begin{array}{l}\mathrm{P} \\
12 \\
14 \\
88 \\
14 \\
19 \\
9 \\
27\end{array}$ & $\begin{array}{l}\mathrm{C} \\
34 \\
29 \\
44 \\
13 \\
23 \\
9 \\
34\end{array}$ \\
\hline
\end{tabular}


Five of the six previously reported studies in which an association between coeliac disease and DR7 was found were from paediatric centres. Of the two studies recording an association with DR3 alone, one concerned adults only ${ }^{9}$; a second study included a mixed group of children and adults, though $74 \%$ were adults ${ }^{7}$ (table III).

The association of coeliac disease with DR3 and DR7 may be interpreted on the basis of more than one model. The condition may, for example, be genetically homogenous and dependent on a susceptibility gene at a locus linked to the DR locus and in linkage disequilibrium with both DR3 and DR7. In this regard it is relevant that the DC3 specificity at the DC locus is in linkage disequilibrium with DR3 and DR7, and Tosi et al put forward evidence to suggest that the primary association was with DC3.12 A recent study of patients with coeliac disease who were DR3 and DR7 negative, however, failed to confirm this. ${ }^{13}$

Our finding of heterogeneity of the DR association argues against this simple model and suggests the possibility of more than one susceptibility gene-namely, DR3 and DR7 or genes in linkage disequilibrium, one with DR3 and one with DR7. If the presence of both genes promotes an early onset of disease, and the presence of only DR3 or a gene in linkage disequilibrium with DR3 a later onset, the present findings would be explained.

Further studies of the association of coeliac disease with DR and DC antigens are being carried out, and it seems important that age of onset of disease should be taken into account. Other than the age of onset, HLA differences do not seem to have any influence on other clinical variables. Kumar et al found that HLA factors did not appear to make any difference to the mode of presentation. ${ }^{14}$

\section{References}

1 Ek J, Albrechsten D, Solheim BG, Thorsby E. Strong association between HLA-DW 3 related B-cell alloantigen-DRW 3 and coeliac disease. Scand $\mathscr{f}$ Gastroenterol 1978;13:229-33.

2 Scholz S, Rossipal E, Brautbar Ch, et al. HLA-DR antigens in coeliac disease. A population and multiple case family study. In: McConnell RB, ed. Th genetics of coeliac disease. Lancaster: MTP Press Ltd, 1981:143-9.

3 DeMarchi M, Borelli I, Olivetti E, et al. Two HLA-D and DR antigens are associated with coeliac disease. Tissue Antigens 1979;14:309-16.

4 Polanco I, Biemond I, Van Leeuwen A, et al. Gluten sensitive enteropathy in Spain: genetic and environmental factors. In: McConnell RB, ed. The genetics of coeliac disease. Lancaster: MTP Press Ltd, 1981:211-31.

5 Betuel H, Gebuhrer L, Percebois H, Descos L, Minaire Y, Bertrand J. Association de la maladie coeliaque de l'adults avec HLA-DRW3 et DRW7. Gastroenterol Clin Biol 1979;3:605-6.

6 Verkasalo M, Tilikainen A, Kuitunen P, Savilahti E, Backman A. HLA antigens and atopy in children with coeliac disease. Gut 1983;24:306-10.

7 McKenna R, Stevens FM, Bourke M, McNicholl B, Albert ED, McCarthy CF $B$-cell alloantigens associated with coeliac disease in the west of Ireland. In: McConnell RB, ed. The genetics of coeliac disease. Lancaster: MTP Press Ltd, $1981: 153-8$.

8 Pena AS, Biemond I, Rosekrans PCM, Van Leeuwen A, Schreuder I, Van Rood JJ. DR locus-controlled B-cell alloantigens in coeliac disease in the Netherlands. In: McConnell RB, ed. The genetics of coeliac disease. Lancaster MTP Press Ltd, 1981:161-8.

9 Ellis A, Evans DAP, McConnell RB, Woodrow JC. Liverpool coeliac family study. In: McConnell RB, ed. The genetics of coeliac disease. Lancaster: MTP Press Ltd, $1981: 265-86$

10 Meeuwisse SGW. Diagnostic criteria in coeliac disease. (Discussion European Society for Paediatric Gastroenterology.) Acta Paediatr Scand 1970;59:461-5.

11 Van Rood JJ, van Leeuwen A, Ploem JS. Simultaneous detection of two cell populations by two-colour fluorescence and application to the recognition of B-cell determinants. Nature $1976 ; 262: 795-7$.

12 Tosi R, Vismara D, Tanigaki N, et al. Evidence that coeliac disease is primarily associated with a DC locus allelic specificity. Clin Immunol Immunopathol 1983;28:395-404.

13 De Marchi M, Carbonara AO. DR3 and DR7 negative coeliac disease. In Albert E, Mayr WR, ed. Histocompatibility testing. Heidelberg: Springer Verlag. (in press).

14 Kumar P, Oliver RTD, O'Donoghue DP, et al. The relationship of HLA-A, $B$ status to the clinical findings and autoimmunity in coeliac disease. In McConnell RB, ed. The genetics of coeliac disease. Lancaster: MTP Press Ltd, 1981:173-80.

(Accepted 26 September 1984)

\begin{abstract}
Random samples or the entire workforce in nine offices in which similar clerical work was being performed were studied using a doctor administered questionnaire that inquired into symptoms that have been linked with the "sick building syndrome." Five of the offices were fully air conditioned, one had recirculation of air and mechanical ventilation, and three were naturally ventilated. Workers in three air conditioned and three naturally ventilated buildings were interviewed blind. Seven of the buildings were studied at our request in the absence of any known problem. Comparison of prevalences of symptoms between the naturally ventilated and the other buildings showed a repeated pattern of nasal, eye, and mucous membrane symptoms with
\end{abstract}

Department of Thoracic Medicine, Wythenshawe Hospital, Manchester M23 9LT

M J FINNEGAN, MRCP, research registrar

C A C PICKERING, DIH, MRCP, consultant physician

Department of Thoracic Medicine, East Birmingham Hospital, Birmingham B9 5ST

P S BURGE, DIH, MRCP, consultant physician

Correspondence to: Dr M J Finnegan, Department of Clinical Pharmacology, Leicester Royal Infirmary, Leicester. lethargy, dry skin, and headaches. There were highly significant excesses of these six symptoms in the air conditioned buildings when compared by $\chi^{2}$ tests with the naturally ventilated buildings.

It is suggested that these six symptoms represent the sick building syndrome and that the size of the problem is probably greater than is currently recognised. Possible causes are discussed.

\section{Introduction}

The "sick building syndrome" is generally taken to describe a building in which complaints of ill health are more common than might reasonably be expected. The affected buildings are usually offices that have full air conditioning. The excess of complaints of ill health is not usually reflected in an increase in sickness absence. No definition of the size of the problem has previously been systematically attempted, although Turiel et al noted excesses of eye, upper respiratory tract, and chest symptoms in an open comparison of an air conditioned and a naturally ventilated building. ${ }^{1}$ In that study $62 \%$ of the workers in the air conditioned building and $66 \%$ in the naturally ventilated building were interviewed.

Several causes have been postulated for symptoms in office buildings, and, despite much research, no satisfactory explanation of the problem has been found. The postulated causes include formaldehyde (from cavity wall insulation, office 